
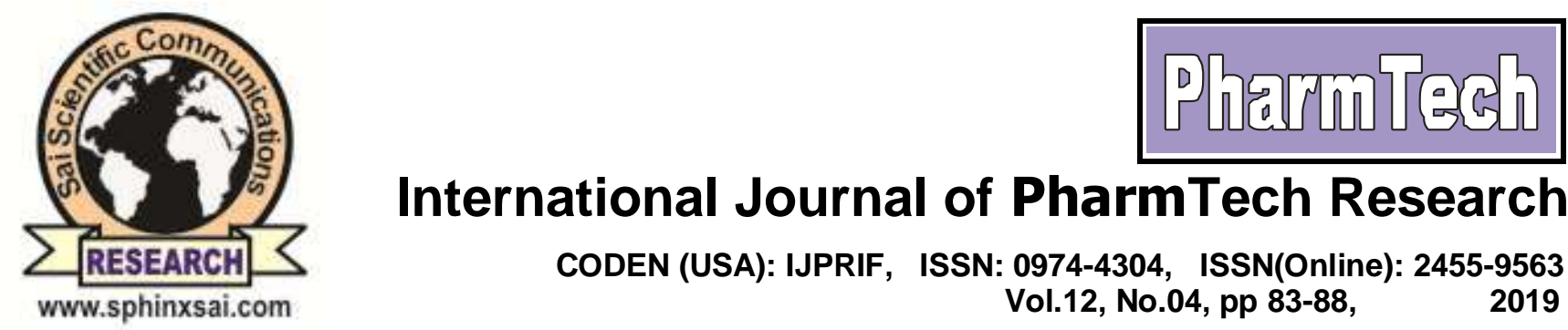

International Journal of PharmTech Research

CODEN (USA): IJPRIF, ISSN: 0974-4304, ISSN(Online): 2455-9563

Vol.12, No.04, pp 83-88,

2019

\title{
Geotechnical Properties of Black Cotton Soil Stabilized with Fly Ash and Geogrids
}

\author{
C.Rajakumar ${ }^{1}$, P. Kodanda Rama Rao ${ }^{2}$ \\ ${ }^{1}$ Associate Professor, Department of Civil Engineering, \\ Gudlavalleru Engineering College, Gudlavalleru, Andhrapradesh, India \\ ${ }^{2}$ Professor \& Head, Department of Civil Engineering, \\ Gudlavalleru Engineering College, Gudlavalleru, Andhrapradesh, India
}

\begin{abstract}
Geotechnical properties of black cotton soil may need to be improved by stabilization to make such soils suitable for construction of highway pavements. Stabilization of such soils has been traditionally depend on treatment with lime, cement, chemicals and waste materials, etc. fly ash is a waste material obtained from thermal power stations. This paper presents the results of stabilization of local black cotton soil with fly ash and geogrid. Series of laboratory tests have been conducted with varying percentage of these stabilizers, added individually with and without geogrids, to determine their optimum percentages. From the results, it is observed that CBR value, for both soaked and unsoaked conditions, increases substantially by addition of $25 \%$ of fly ash with double layer of geogrids. The pavement designed with these improved values of CBR indicated a marked reduction in its thickness leading to economy in the construction of road pavements on or using clayey soils.
\end{abstract}

Keywords : Fly ash, Geogrid, Black Cotton soil, Stabilization, CBR.

\section{Introduction}

Highway pavement construction requires good earth materials in very large quantity. In urban areas, borrowing earth is not easy, as it has to be hauled from a long distance. Quite often, Coimbatore in Tamilnadu is largely covered with highly plastic and expansive soil, which is not suitable to be used as earth material. Extensive laboratory and field studies have been carried out by various researchers Prasad, DSV \& College (2011); Singh et al. (2011); Boominathan and Rathnakumar 1996) and found significant increase in properties of soil for application of such expansive soil after stabilization.

Expansive soils are those that change significantly in volume with changes in water content. The problem with expansive soils has been recorded all over the world. In monsoon they absorb water and swell, where as in summer they shrink on evaporation of water. This alternate swelling and shrinkage severely damages lightly loaded structures like residential buildings, pavements and canal linings. Predominant forms of damages such as cracks, upliftment and settlement are common. It is therefore, necessary to mitigate these 
problems posed by expansive soils and prevent damages of structures. This affects the service of structures and pavements resulting in increased maintenance cost for damages. The need for adequate provisions of transportation facilities are enormously increasing with increase in population and expansion of the city. The available soil in the city is not useful for subgrade preparation. Non-swelling, low plastic soils are transported from faraway places and are used for subgrade preparation. However, this is a temporary process. The quantity of soil required is very high. The demand for non-swelling soil can be solved by converting this high swelling soil into a non-swelling and improved soil. Owing to this fact, continuous researches have been carried and still being carried out by individual, firms and institutions on ways to improve the engineering properties of soils. Most of the available soils do not have adequate engineering properties to really bear the expected wheel load. So improvisations have to be made to make these soils better. This lead to the concept called soil stabilization which can be any treatment (including, compaction) applied to a soil to improve its strength and reduce its vulnerability to water. If the treated soil is able to withstand the stresses imposed on it by traffic under all weather conditions without excessive deformation, then it is generally regarded as stable (Rifa et al., Eka Putri et al. 2012,Osinubi \& Eberemu 2010,Moses \& Osinubi, 2013, Sharma et al. 2012,Sabat 2012, Taskiran 2010,Trivedia et al 2013, Mukesh A. patel, HS Patel, 2013,BIS 2720).

\section{Material and Methods}

\section{Methodology}

Methodology mainly consists of three parts. Part 1 includes identification of problems in construction of roads in black cotton soil, review of literatures, collection of clay, flyash and geogrids. Part 2 and part 3 are laboratory works which are mainly focused on determination of index and engineering, properties of soil with geogrid and flyash mixture (BIS 2720). Methodology is graphically represented by figure 1.

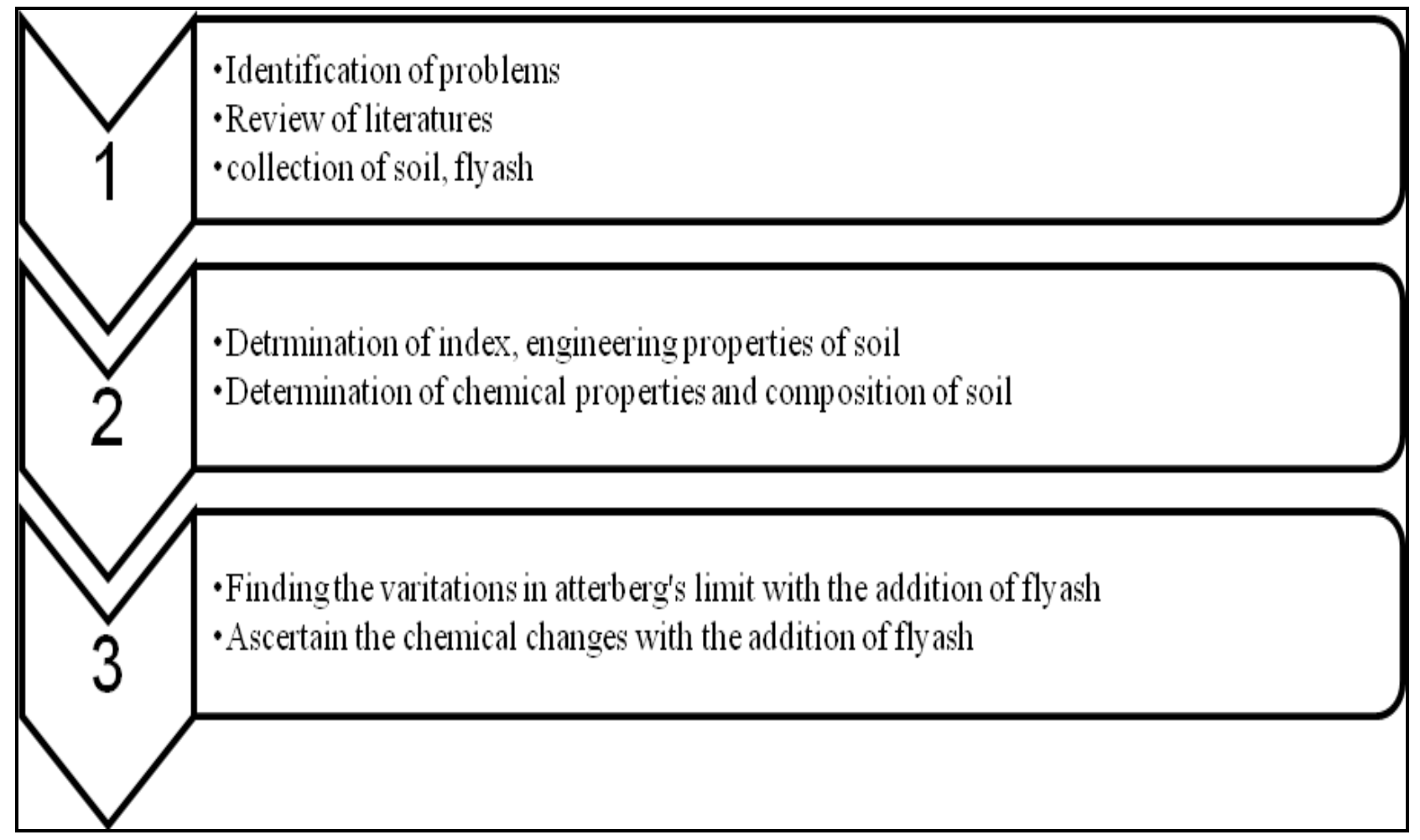

Figure 1 Methodology

\section{Materials}

\section{Collection of Clay}

Clay for this research work is collected from GCT Campus, Coimbatore, Tamilnadu state, India. The locations are $11.0362 \mathrm{~N}, 77.01830 \mathrm{E}$. The soil sample was present at depth of 5 feet from ground level. 


\section{Fly ash and Geogrid}

Industrial waste such as fly ash (Figure 2) was collected from Mettur Thermal Power Station at Mettur and Geogrid (Figure 3) was collected from IVRCL private limited at Avinashi highway project, Avinashi.

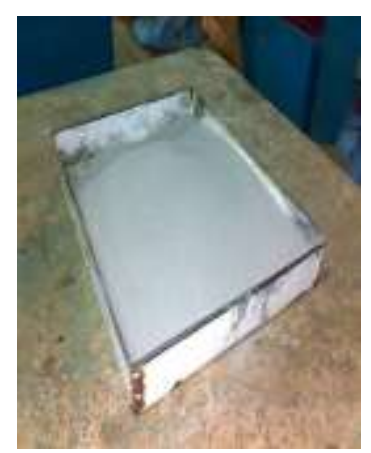

Fig.2 Fly ash

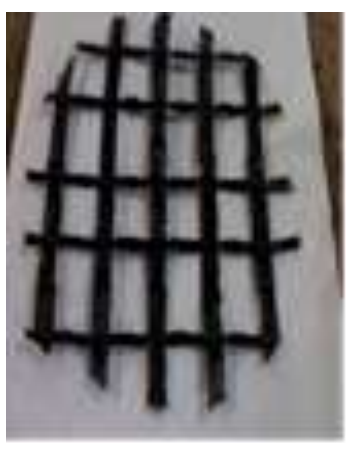

Fig.3 Geo grid

\section{Laboratory Investigation}

Table.1 Properties of Clay

\begin{tabular}{|c|c|c|}
\hline Sl. No. & Properties & Result \\
\hline 1 & Natural Moisture Content & $9.89 \%$ \\
\hline 2 & Specific Gravity & 2.70 \\
\hline 3 & $\begin{array}{l}\text { Sieve Analysis } \% \text { of Gravel } \\
\% \text { of sand } \\
\% \text { of Silt } \\
\% \text { of Clay }\end{array}$ & $\begin{array}{l}2.1 \% \\
25.3 \% \\
22.1 \% \\
50.6 \%\end{array}$ \\
\hline 4 & Differential Free Swell Index & $60 \%$ \\
\hline \multirow{10}{*}{5} & Liquid Limit $\left(\mathrm{W}_{\mathrm{L}}\right)$ & $57 \%$ \\
\hline & Plastic Limit $\left(\mathrm{W}_{\mathrm{P}}\right)$ & $17 \%$ \\
\hline & Shrinkage Limit $\left(\mathrm{W}_{\mathrm{S}}\right)$ & $12 \%$ \\
\hline & Flow Index $\left(\mathrm{I}_{\mathrm{f}}\right)$ & 24 \\
\hline & Plasticity Index $\left(\mathrm{I}_{\mathrm{P}}\right)$ & $40 \%$ \\
\hline & Toughness Index $\left(\mathrm{I}_{\mathrm{t}}\right)$ & 1.15 \\
\hline & Liquidity $\operatorname{Index}\left(\mathrm{I}_{\mathrm{L}}\right)$ & $-27 \%$ \\
\hline & Consistency Index $\left(\mathrm{I}_{\mathrm{C}}\right)$ & $117.7 \%$ \\
\hline & Soil Classification & $\mathrm{CH}$ \\
\hline & Activity (A) & 0.55 \\
\hline \multirow{2}{*}{6} & Optimum Moisture Content & $15 \%$ \\
\hline & Maximum Dry Density & $1.7 \mathrm{~g} / \mathrm{cc}$ \\
\hline \multirow{2}{*}{7} & Unconfined Compressive Strength $\left(\mathrm{q}_{\mathrm{u}}\right)$ & $92.5 \mathrm{kN} / \mathrm{m}^{2}$ \\
\hline & Cohesion $\left(\mathrm{C}_{\mathrm{u}}\right)$ & $46.25 \mathrm{kN} / \mathrm{m}^{2}$ \\
\hline 8 & $\begin{array}{l}\text { CBR unsoaked } \\
\text { CBR soaked }\end{array}$ & $\begin{array}{l}13.88 \% \\
2.79 \%\end{array}$ \\
\hline
\end{tabular}


Laboratory tests are conducted in the laboratory with the collected soil sample to classify the clay, to evaluate its physical and engineering properties and study the compaction characteristics. Standard Proctor Compaction Test ,Unconfined Compressive Strength Test, CBR (unsoaked and soaked) tests are conducted on samples with 5\%,10\%, 15\%, 20\%, 25\% and 30\% addition of fly ash with single and double layer of geogrid combinations. The Standard Proctor Compaction tests are conducted on the sample to evaluate the Optimum Moisture Content and Maximum dry density of soils. Unconfined Compressive Strength tests are conducted to evaluate the unconfined compressive strength and cohesion. The CBR value for the virgin soil is obtained. Results are analyzed and conclusions are made based on the results (BIS 2720). The results are reported in

\section{Experimental Study}

Experimental study elaborates on various engineering properties of soil such as natural moisture content, specific gravity, liquid limit, plastic limit, shrinkage limit, particle size distribution, Optimum Moisture Content, Maximum Dry Density, Unconfined Compressive Strength(UCS), California Bearing Ratio (CBR), free swell Index etc (Taskiran 2010,Trivedia et al 2013, Mukesh A. patel, HS Patel, 2013,BIS 2720) .

\section{Compaction Test}

Standard Proctor Compaction tests are conducted on soil samples with addition of coal ash in proportions of $5 \%, 10 \%, 15 \%, 20 \%, 25 \%$ and $30 \%$ of the weight of soil samples with single and double layer of geogrids (Figure 4). The variation of Maximum Dry Density and Optimum Moisture Content is recorded (Taskiran 2010,Trivedia et al 2013, Mukesh A. patel, HS Patel, 2013,BIS 2720).
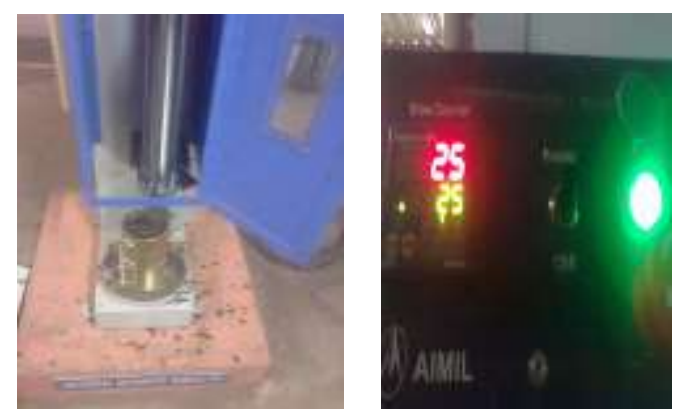

Figure 4. Automatic compaction machine

\section{Unconfinedcompressive Strength Test}

Unconfined Compressive Strength tests are conducted on soil samples with addition of coal ash in proportions of $5 \%, 10 \%, 15 \%, 20 \%, 25 \%$ and $30 \%$ of the weight of soil samples. The variation of unconfined compressive strength is shown in figure 5-8 (Taskiran 2010,Trivedia et al 2013, Mukesh A. patel, HS Patel, 2013,BIS 2720).
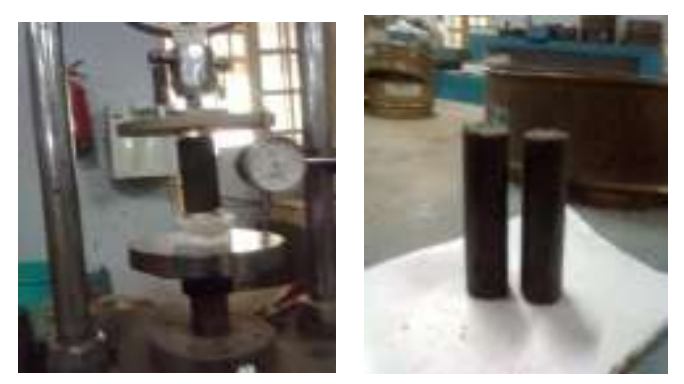

Figure.5 UCC test apparatus with specimen 


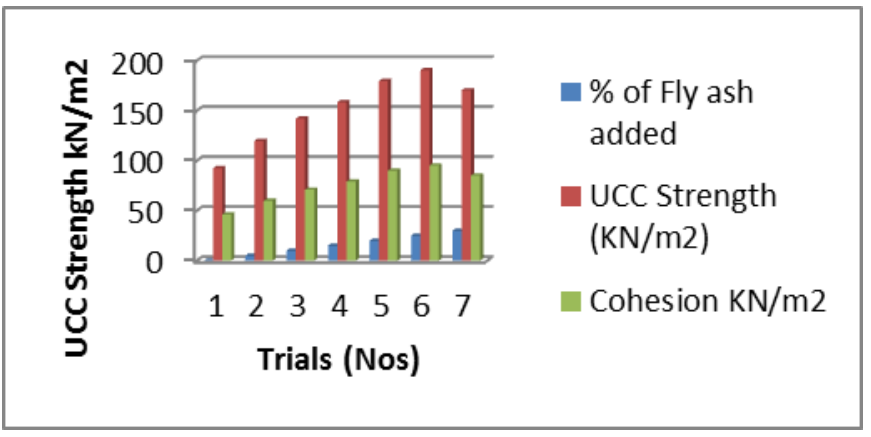

Figure.6 UCC strength of clay stabilized with fly ash

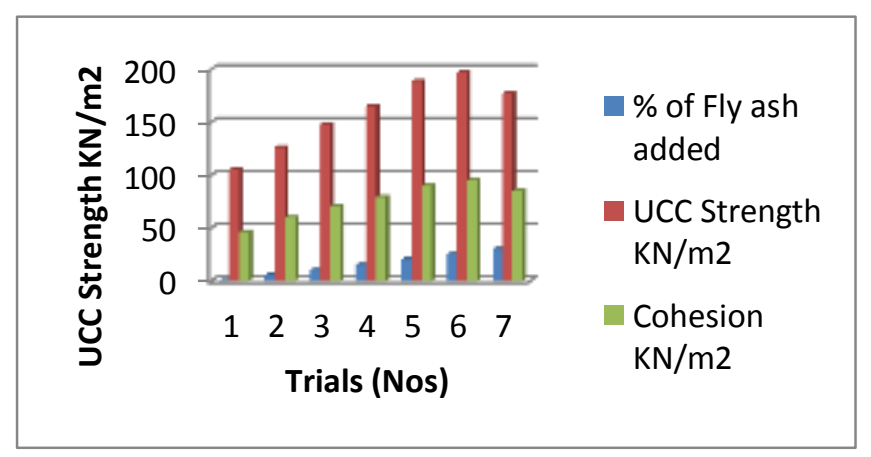

Figure.7 UCC Strength of clay stabilized with fly ash and single layer of geogrid

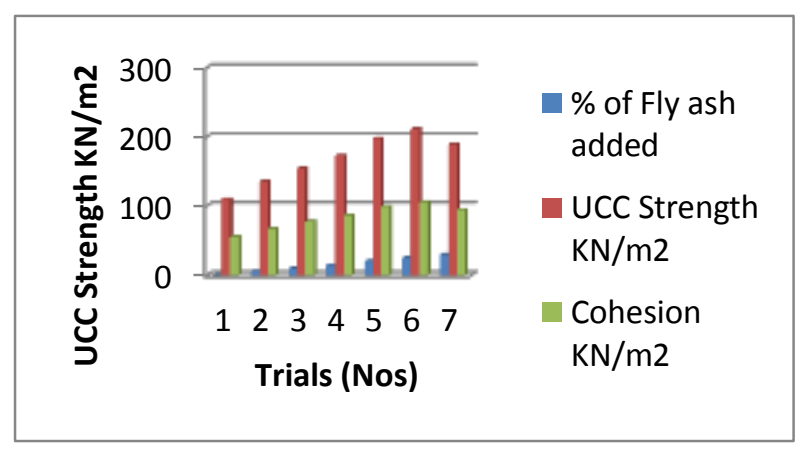

Figure.8 UCC Strength of clay stabilized with fly ash and double layer of geogrid

\section{California Bearing Ratio Test}

California bearing ratio tests are conducted in order to determine the California bearing ratio value for soil with optimum percent of fly ash. The samples are compacted at optimum moisture content for both unsoaked and soaked test with single and double layer of geogrid (Figure.9).
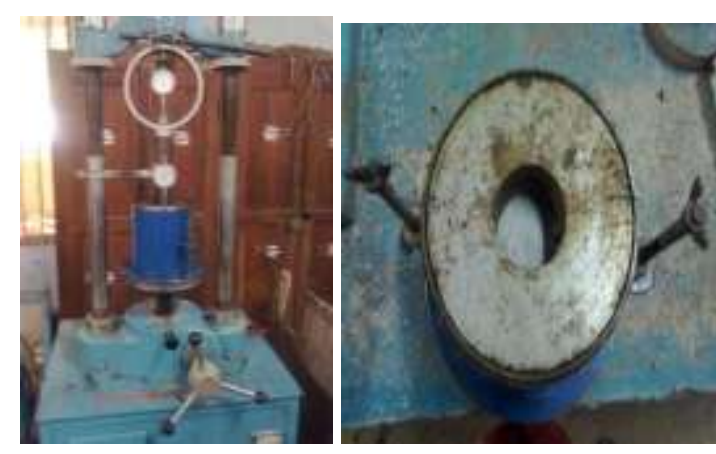

Figure.9 CBR Test with compacted sample 


\section{Conclusions}

Based on the experimental investigations on stabilization of clay, the following conclusions are drawn.

1. The initial laboratory investigations showed that collected clay soil sample is solid, stiff and has high compressibility.

2. The optimum percentage replacement of fly ash is found to be $25 \%$ with double layer of geogrid.

3. The results improved at $25 \%$ replacement are as follows - The liquid limit, plasticity index decreases and maximum dry density shows a significant change.

4. $\quad$ 4.The optimum moisture content increases with increase in fly ash replacement.

5. The unconfined compressive strength of untreated soil is $92.5 \mathrm{KN} / \mathrm{m}^{2}$. The addition of fly ash has increased the UCC strength to $211.48 \mathrm{KN} / \mathrm{m}^{2}$ at $25 \%$ fly ash with double layer of geogrid.

6. The blend suggested from this investigation is clay with $25 \%$ replacement by fly ash with double layer of geogrid, would be an economical approach.

7. Furthermore if the soil reinforcement is provided, there will be more perfection in properties of expansive soil.

\section{References}

1. Jyoti S.Trivedia, Sandeep Nair, Chakradhar Iyyunni, 2013, "Optimum Utilization of Fly Ash for Stabilization of Sub-Grade Soil using Genetic Algorithm”, Procedia Engineering 51 (2013 ) 250 258

2. Mukesh A. patel, HS Patel, 2013, "Laboratory Assessment to Correlate Strength Parameter from Physical properties of Subgrade", Procedia Engineering 51 -(2013), 200 - 209

3. T. Taskiran, 2010, "Prediction of California bearing ratio (CBR) of fine grained soils by AI methods", Advances in Engineering Software 41 (2010) 886-892

4. Ambarish Ghosh, Utpal Dey, 2009, "Bearing ratio of reinforced fly ash overlying soft soil and deformation modulus of fly ash", Geotextiles and Geomembranes 27 (2009) ,313-320

5. Ahmad rifa'i, Noriyuki yasufuku, Kiyoshi omine and Kazuyoshi tsuji,2009, "Experimental study of coal ash utilization for road application on soft soil", Geotechnical Society of Singapore (GeoSS).2009,356-362

6. Pandian NS, 2004, "Fly ash characterization with reference to geotechnical applications", Journal of IISc, 84,189-216.

7. Phani Kumar SR, Sharma RS (2004), "Effect of fly ash on engineering properties of expansive soils", Journal of Geotechnical and Geo environmental Engineering, 130(7):764-767

8. Sharma NK, 2011, "Stabilization of clayey soil with fly ash and lime: A micro level investigation", Geotechnical and Geological Engineering.

9. IS: 2720 (Part 2) - 1973 (Determination of Water Content)

10. IS: 2720 (Part 3/Section 1) - 1980 [Part 3 - Determination Of Specific Gravity (Section -1 Fine Grained Soils)]

11. IS: 2720 (Part 4) - 1985 (Grain Size Analysis)

12. IS: 2720 (Part 40) -1977 (Determination of Free Swell Index of Soils)

13. IS: 2720 (Part 5) -1985 (Determination of Liquid and Plastic Limit)

14. IS: 1498-1970 (Classification and Identification of Soils for general engineering purposes)

15. IS: 2720 (Part 7) -1980 (Determination Of Water Content-Dry Density Relation Using Light Compaction)

16. IS: 2720 (Part 10) -1991 (Determination of Unconfined Compressive Strength)

17. IS: 2720 (Part 16) -1987 (Laboratory Determination of CBR) 